\title{
Who Voted for Trump in 2016?
}

\author{
Alexandra C. Cook, Nathan J. Hill, Mary I. Trichka, Grace J. Hwang, Paul M. Sommers* \\ Department of Economics, Middlebury College, Middlebury, VT, USA \\ Email: *psommers@middlebury.edu
}

How to cite this paper: Cook, A.C., Hill, N.J., Trichka, M.I., Hwang, G.J. and Sommers, P.M. (2017) Who Voted for Trump in 2016? Open Journal of Social Sciences, 5, 199-210.

https://doi.org/10.4236/jss.2017.57013

Received: July 5, 2017

Accepted: July 14, 2017

Published: July 17, 2017

Copyright $\odot 2017$ by authors and Scientific Research Publishing Inc. This work is licensed under the Creative Commons Attribution International License (CC BY 4.0).

http://creativecommons.org/licenses/by/4.0/

\begin{abstract}
The authors use simple bilinear regression on statewide exit poll data to gauge the popularity of President Donald Trump in the 2016 election among voters in four levels of educational attainment (high school, some college, college, and postgraduate); three income groups (less than $\$ 50,000, \$ 50,000-\$ 100,000$, and more than $\$ 100,000)$; four age groups (18 - 29, $30-44,45-64$, and $65+$ ); and two racial groups (white and non-white). Trump was found to be most popular among voters with a high school education, voters with annual incomes greater than $\$ 100,000$, voters 65 years of age or older and white voters. Trump was found to be least popular among voters with a postgraduate degree, voters with annual incomes less than $\$ 50,000$, voters under 30 years of age and non-white voters.
\end{abstract}

\section{Keywords}

Regression, Exit Polls, Presidential Elections

\section{Introduction}

The night before the 2016 presidential election, statistician and editor-in-chief of ESPN's Five Thirty Eight Nate Silver gave Donald Trump a 28.6 percent chance of winning the presidency (Silver [1]). On Tuesday, November $8^{\text {th }}$, however, Donald Trump became the president-elect after winning the electoral votes in the key states of Florida (with 29 electoral votes), Pennsylvania (20), Michigan (16) and Wisconsin (10). ${ }^{1}$ Throughout the presidential race, Trump claimed to have the support of the "silent majority." What is the demographic makeup of this majority? In this paper, the educational attainment level, annual income, age, and the racial identity of voters who supported Trump in 2016 are examined.

Exit poll data from 28 states on four levels of educational attainment (high school, some college, college, and post-graduate); three income groups (less than ${ }^{1}$ If Hillary Clinton had won Florida and one of the other three states listed, she would have collected enough electoral votes to win the election. 
$\$ 50,000, \$ 50,000-\$ 100,000$, and more than $\$ 100,000)$; four age groups (18 - 29, 30 - 44, 45 - 64, and 65+); and two racial groups (white and non-white) were collected from the 2016 election (CNN Politics [2]). ${ }^{2}$ Exit poll data on education, income, age, and race are shown in Table 1 . The purpose of this paper is to show

Table 1. President Donald Trump's Support in 2016 (percentage of vote).

\begin{tabular}{|c|c|c|c|c|c|c|c|c|}
\hline \multirow{3}{*}{ State } & \multirow{3}{*}{$\begin{array}{l}\text { Overall } \\
\text { Popular } \\
\text { Vote } \\
\text { (percent) }\end{array}$} & \multicolumn{7}{|c|}{ Exit Poll Results } \\
\hline & & \multicolumn{4}{|c|}{ Education } & \multicolumn{3}{|c|}{ Income } \\
\hline & & $\begin{array}{l}\text { High } \\
\text { School }\end{array}$ & $\begin{array}{l}\text { Some } \\
\text { College }\end{array}$ & College & Post-graduate & $<50$ & $50-100$ & $>100$ \\
\hline Arizona & 49.0 & 52 & 49 & 51 & 39 & 40 & 48 & 54 \\
\hline California & 31.9 & 31 & 39 & 32 & 27 & 24 & 26 & 40 \\
\hline Colorado & 43.3 & 51 & 49 & 43 & 30 & 41 & 44 & 41 \\
\hline Florida & 49.0 & 46 & 49 & 54 & 39 & 42 & 52 & 56 \\
\hline Georgia & 51.0 & 57 & 51 & 49 & 47 & 48 & 49 & 56 \\
\hline Illinois & 38.9 & 39 & 43 & 38 & 33 & 37 & 36 & 45 \\
\hline Indiana & 57.2 & 66 & 61 & 56 & 41 & 52 & 63 & 62 \\
\hline Iowa & 51.7 & 51 & 56 & 53 & 36 & 38 & 55 & 51 \\
\hline Kentucky & 62.5 & 66 & 64 & 67 & 42 & 58 & 65 & 68 \\
\hline Maine & 45.0 & 63 & 51 & 43 & 22 & 47 & 44 & 41 \\
\hline Michigan & 47.6 & 49 & 49 & 50 & 33 & 42 & 51 & 51 \\
\hline Minnesota & 45.3 & 55 & 55 & 45 & 27 & 45 & 48 & 41 \\
\hline Missouri & 56.9 & 62 & 57 & 56 & 53 & 48 & 59 & 66 \\
\hline Nevada & 45.5 & 42 & 48 & 45 & 44 & 31 & 42 & 58 \\
\hline New Hampshire & 47.2 & 58 & 53 & 48 & 29 & 43 & 46 & 47 \\
\hline New Jersey & 41.4 & 48 & 49 & 41 & 29 & 31 & 43 & 46 \\
\hline New Mexico & 40.0 & 42 & 43 & 41 & 32 & 33 & 46 & 43 \\
\hline New York & 36.8 & 47 & 42 & 35 & 30 & 30 & 37 & 38 \\
\hline North Carolina & 50.5 & 54 & 52 & 50 & 44 & 38 & 50 & 60 \\
\hline Ohio & 51.8 & 49 & 54 & 54 & 49 & 43 & 55 & 59 \\
\hline Oregon & 40.6 & 57 & 46 & 32 & 24 & 40 & 44 & 36 \\
\hline Pennsylvania & 48.6 & 56 & 49 & 50 & 37 & 42 & 55 & 52 \\
\hline South Carolina & 54.9 & 58 & 58 & 52 & 54 & 47 & 55 & 64 \\
\hline Texas & 52.5 & 49 & 54 & 53 & 48 & 44 & 49 & 53 \\
\hline Utah & 45.5 & 55 & 52 & 39 & 37 & . & . & . \\
\hline Virginia & 44.8 & 52 & 51 & 44 & 33 & 41 & 49 & 44 \\
\hline Washington & 38.1 & 33 & 48 & 37 & 28 & 36 & 44 & 34 \\
\hline Wisconsin & 47.8 & 54 & 57 & 45 & 26 & 45 & 52 & 46 \\
\hline
\end{tabular}

${ }^{2}$ In 2016, CNN reported exit poll data for 28 states. Exit poll data was drawn from a small percentage of voters immediately after leaving the polling station. In the state of Utah, there was no exit poll data taken for income groups. In the states of Oregon and Washington, there was no exit poll data taken for voters 18 to 29 years of age. 


\section{Continued}

\begin{tabular}{|c|c|c|c|c|c|c|c|}
\hline \multirow{3}{*}{ State } & \multirow{3}{*}{$\begin{array}{l}\text { Overall Popular } \\
\text { Vote (percent) }\end{array}$} & \multicolumn{6}{|c|}{ Exit Poll Results } \\
\hline & & \multicolumn{4}{|c|}{ Age } & \multicolumn{2}{|r|}{ Race } \\
\hline & & $18-29$ & $30-44$ & $45-64$ & $65+$ & White & Non-White \\
\hline Arizona & 49.0 & 35 & 41 & 54 & 55 & 54 & 32 \\
\hline California & 31.9 & 23 & 27 & 39 & 36 & 45 & 21 \\
\hline Colorado & 43.3 & 36 & 45 & 45 & 48 & 47 & 31 \\
\hline Florida & 49.0 & 36 & 39 & 56 & 57 & 64 & 24 \\
\hline Georgia & 51.0 & 33 & 44 & 57 & 67 & 75 & 14 \\
\hline Illinois & 38.9 & 28 & 33 & 43 & 61 & 52 & 13 \\
\hline Indiana & 57.2 & 46 & 57 & 63 & 58 & 64 & 27 \\
\hline Iowa & 51.7 & 48 & 52 & 53 & 51 & 54 & 25 \\
\hline Kentucky & 62.5 & 59 & 66 & 63 & 61 & 68 & 20 \\
\hline Maine & 45.0 & 43 & 50 & 47 & 39 & 46 & 33 \\
\hline Michigan & 47.6 & 34 & 48 & 52 & 51 & 57 & 17 \\
\hline Minnesota & 45.3 & 42 & 39 & 52 & 47 & 50 & 22 \\
\hline Missouri & 56.9 & 51 & 48 & 63 & 62 & 66 & 22 \\
\hline Nevada & 45.5 & 35 & 40 & 54 & 47 & 56 & 28 \\
\hline New Hampshire & 47.2 & 41 & 43 & 51 & 49 & 48 & 33 \\
\hline New Jersey & 41.4 & 30 & 40 & 44 & 49 & 54 & 17 \\
\hline New Mexico & 40.0 & 27 & 38 & 46 & 42 & 47 & 32 \\
\hline New York & 36.8 & 24 & 33 & 43 & 44 & 51 & 13 \\
\hline North Carolina & 50.5 & 35 & 46 & 55 & 60 & 63 & 18 \\
\hline Ohio & 51.8 & 42 & 51 & 56 & 56 & 62 & 15 \\
\hline Oregon & 40.6 & & 40 & 42 & 45 & 42 & 24 \\
\hline Pennsylvania & 48.6 & 43 & 42 & 52 & 54 & 56 & 16 \\
\hline South Carolina & 54.9 & 43 & 51 & 62 & 58 & 70 & 12 \\
\hline Texas & 52.5 & 36 & 48 & 59 & 64 & 69 & 29 \\
\hline Utah & 45.5 & 35 & 38 & 51 & 65 & 48 & 26 \\
\hline Virginia & 44.8 & 36 & 40 & 50 & 52 & 59 & 17 \\
\hline Washington & 38.1 & & 36 & 43 & 41 & 40 & 31 \\
\hline Wisconsin & 47.8 & 44 & 37 & 56 & 49 & 53 & 21 \\
\hline
\end{tabular}

Source: http://edition.cnn.com/election/results/exit-polls/national/president.

how simple bilinear regression on exit poll data, in conjunction with the actual percentage of each state's Trump voters, can be used to highlight Trump's relative popularity across different levels of educational attainment, income, age, and racial groups. Thus, this method of analysis can also be used to gauge any candidate's relative popularity among different demographic and socioeconomic groups. 


\section{Methodology}

Figure 1 shows a scatter plot of the actual percentage of Trump voters versus the percentage of Trump voters with a high school education. Each point represents a state whose actual percentage of Trump voters can be read along the vertical axis and percentage of Trump voters with a high school education (based on exit polls) can be read along the horizontal axis. What is the relationship between Trump's actual percentage of the total vote [ Trump(actual)] and his support among voters with a high school education [ Trump(high school)], on average? The estimated regression equation that summarizes this relationship would be given by:

$$
\operatorname{Trump}(\text { actual })=b_{o}+b_{1} \operatorname{Trump}(\text { high school })
$$

If, in all states, the percentage of Trump voters with a high school education was equal to the actual percentage of all voters who cast their ballots for Trump, then all points in Figure 1 (where each point represents a state) would fall on a 45-degree line, given by:

$$
\operatorname{Trump}(\text { actual })=\operatorname{Trump}(\text { high school })
$$

The regression equation and the 45-degree line intersect at a single point, where Trump(actual) is equal to Trump(high school), hereafter called the critical point $x^{*}$, where:

$$
x^{*}=\frac{b_{0}}{\left(1-b_{1}\right)}
$$

If, as shown in Figure $1, x^{*}$ is equal to 40.8 , the regression analysis predicts that, on average, in states where Trump received 40.8 percent or more of the state's total vote, he was more popular with high school educated voters than he was with the state's general population. In fact, Trump received at least 40.8 percent of the vote in 22 of the 28 states in our sample (see Table 1), a result that

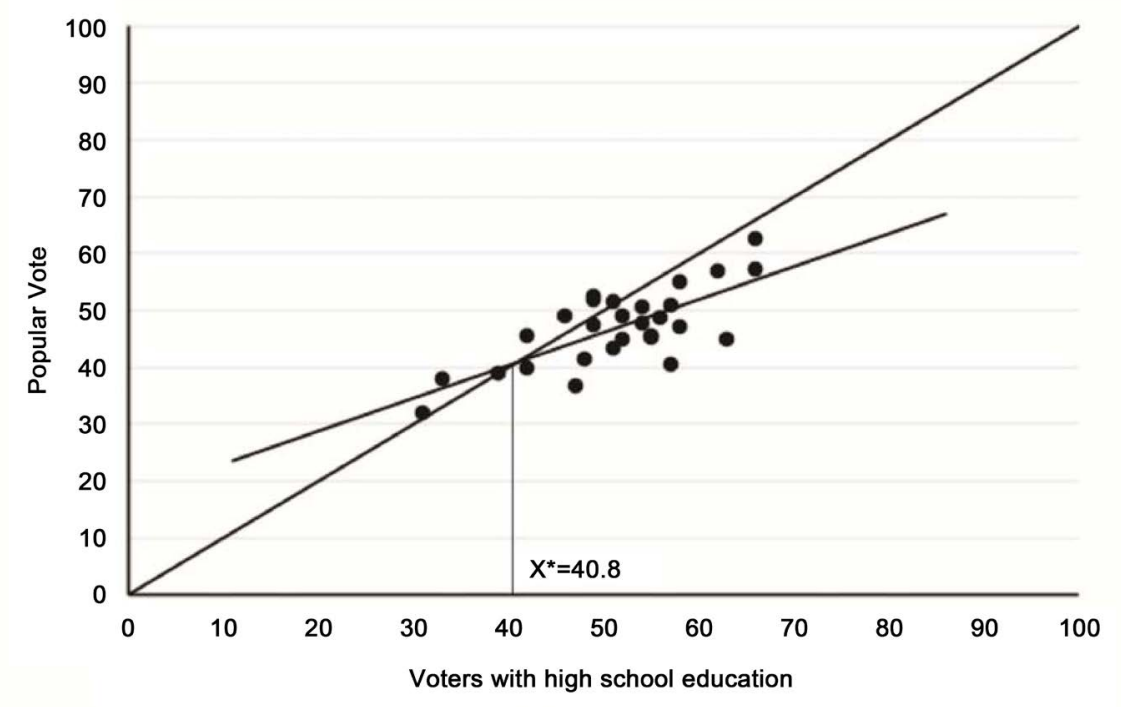

Figure 1. Exit poll results 2016, Trump voters with a high school education. 
underscores his strong popularity among voters with at most a high school degree.

\section{Presentation of Results}

Scatter plots including the regression line, a 45-degree line, and the critical point for each variable are shown in Figures 2-13. (The data source for all points in Figures 1-13 is http://edition.cnn.com/election/results/exit-polls/national/president.) Table 2 summarizes the results of each regression for four educational attainment levels, three annual income groups, four age groups, and two racial groups. The last column of Table 2 gives the critical points of intersection between the regression line and a 45-degree line. Based on these critical points, Trump received

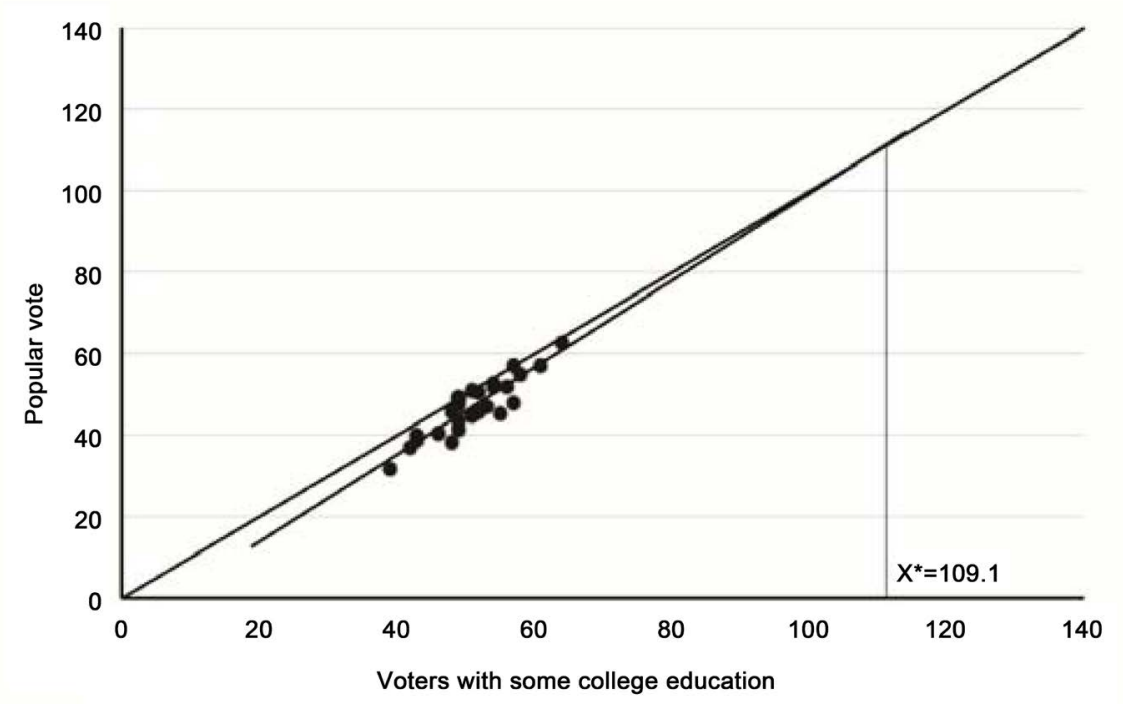

Figure 2. Exit poll results 2016, Trump voters with some college education.

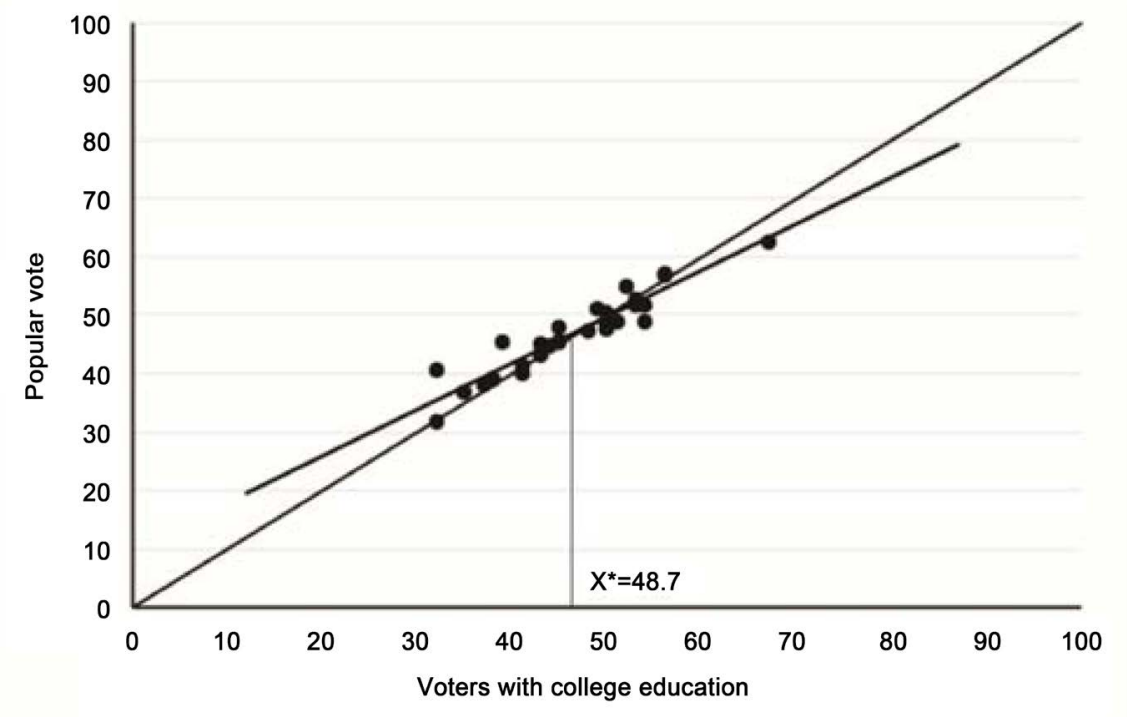

Figure 3. Exit poll results 2016, Trump voters with a college education. 


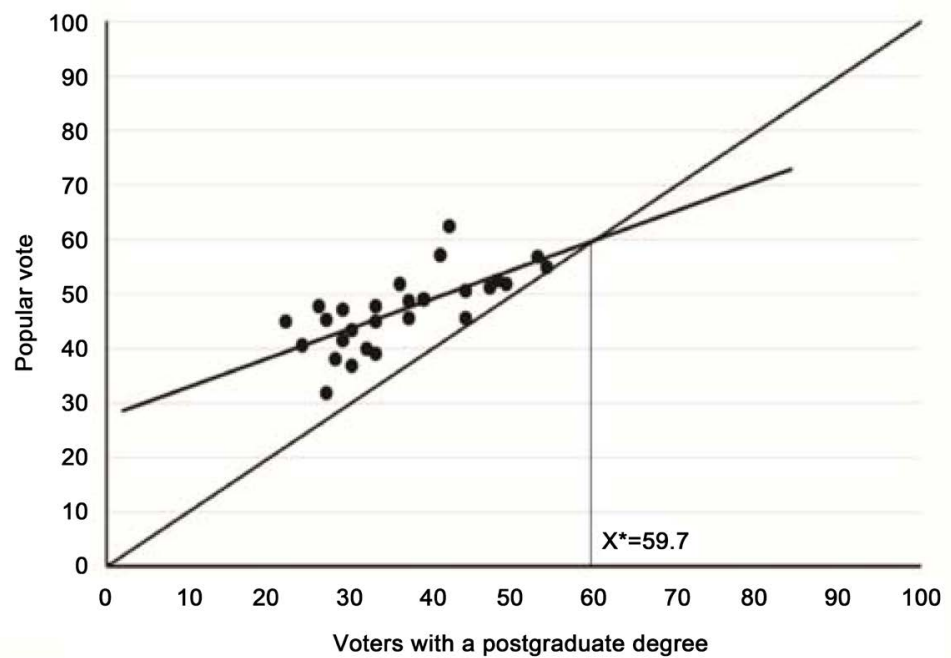

Figure 4. Exit poll results 2016, Trump voters with a postgraduate degree.

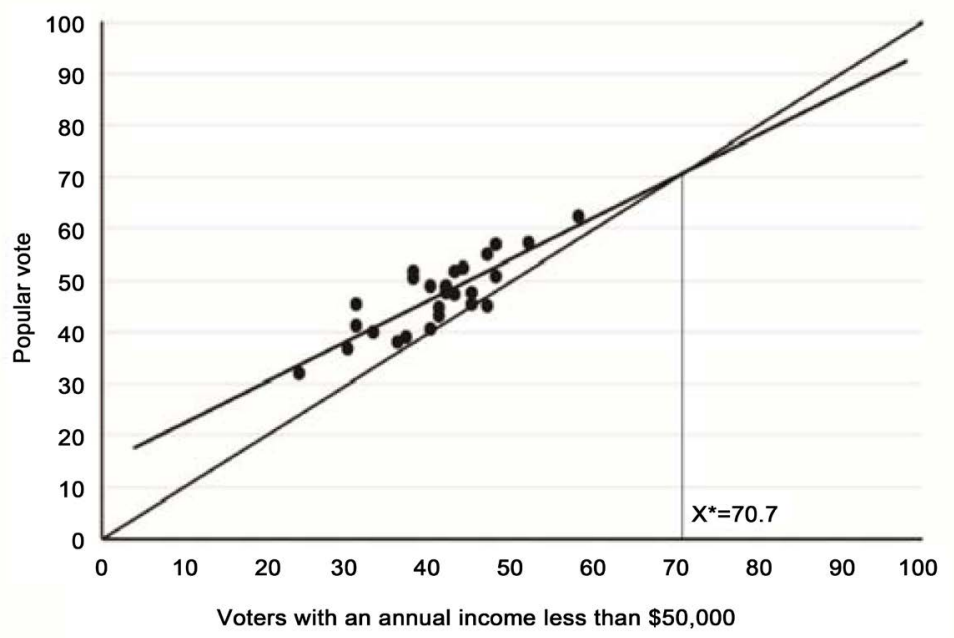

Figure 5. Exit poll results 2016, Trump voters with annual incomes less than $\$ 50,000$.

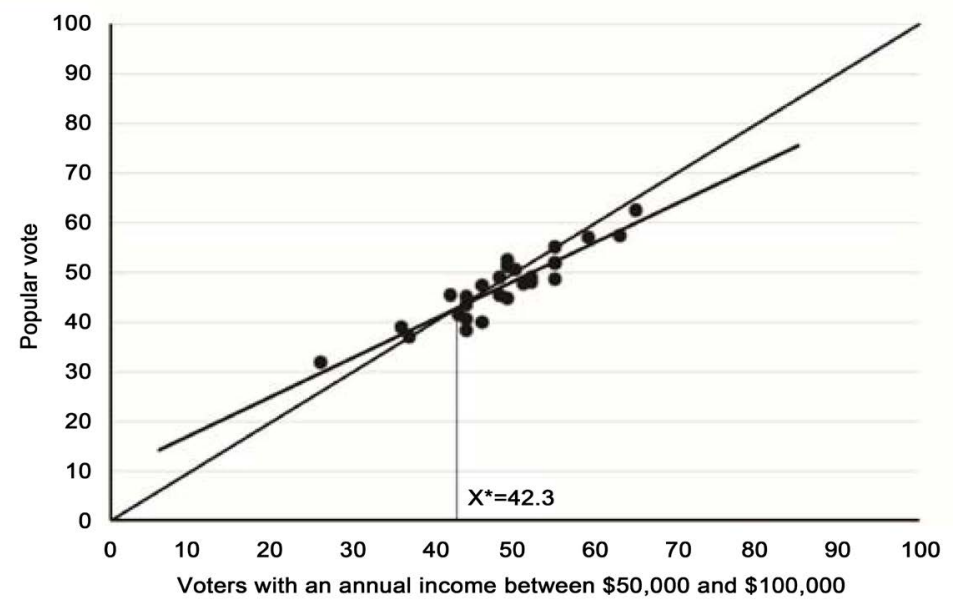

Figure 6. Exit poll results 2016, Trump voters with annual incomes between $\$ 50,000$ and $\$ 100,000$. 


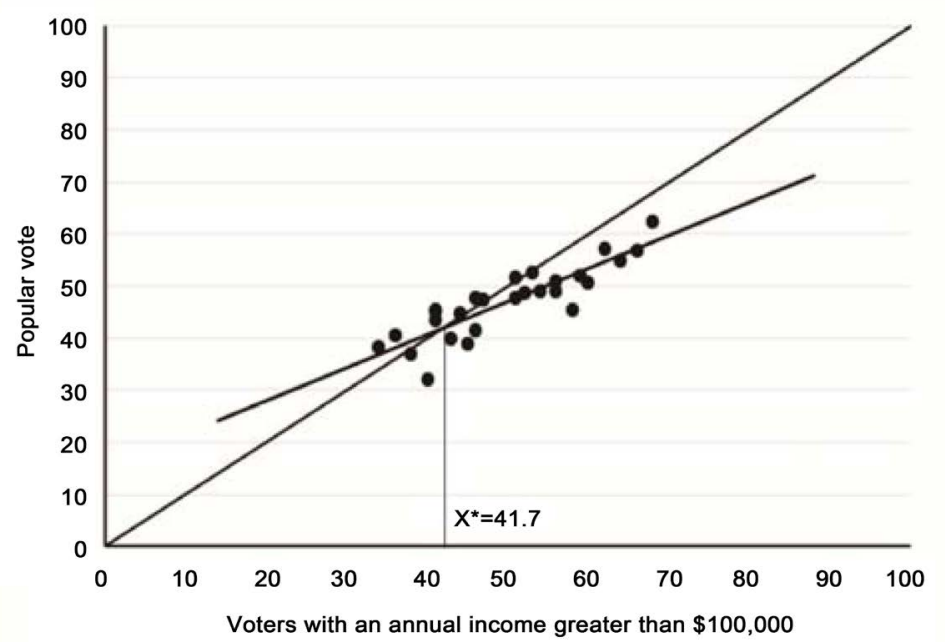

Figure 7. Exit poll results 2016, Trump voters with annual incomes greater than $\$ 100,000$.

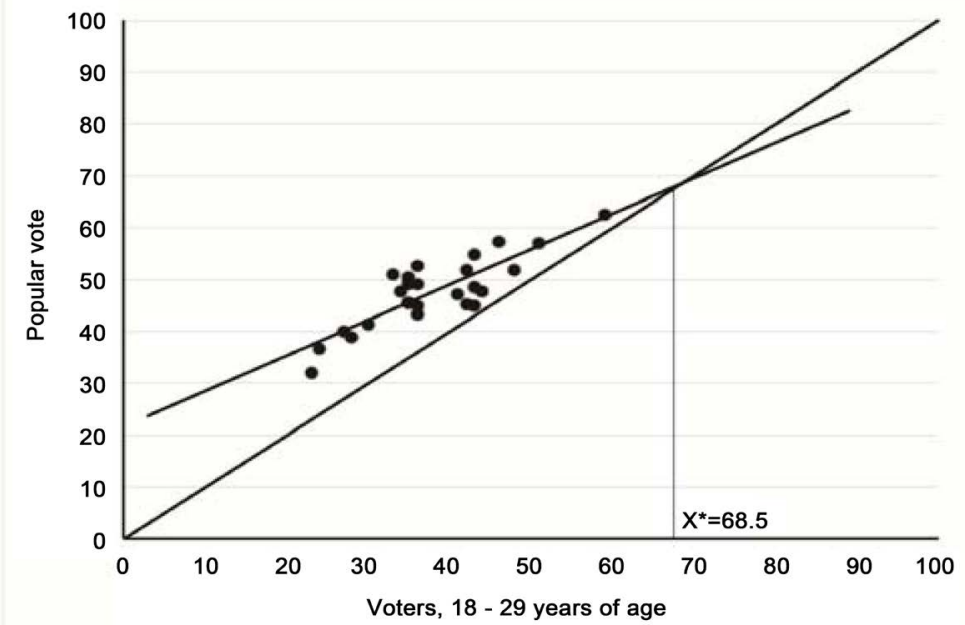

Figure 8. Exit poll results 2016, Trump voters ages 18 - 29.

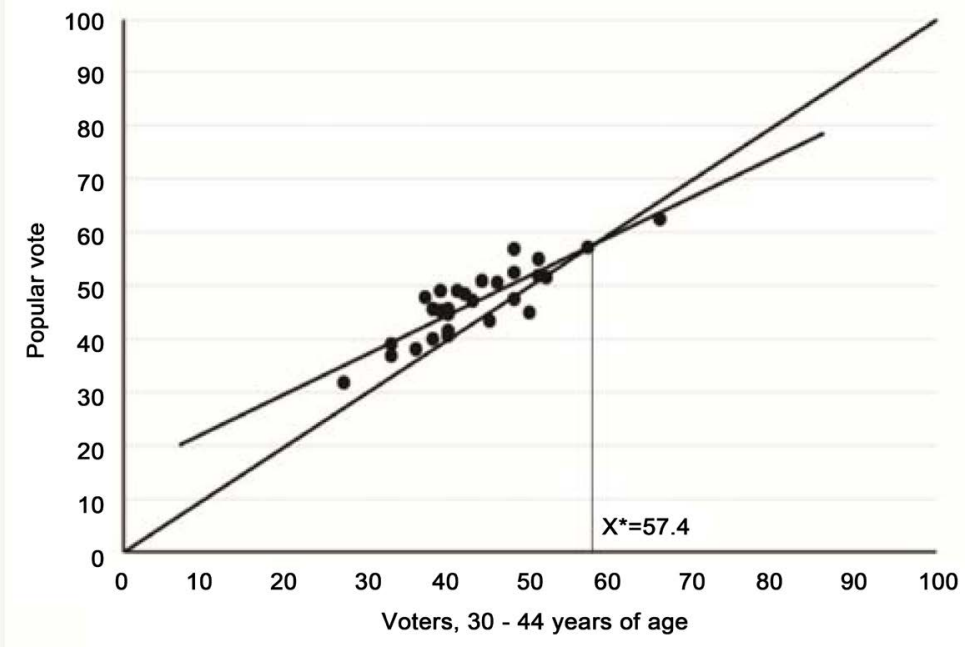

Figure 9. Exit poll results 2016, Trump voters ages 30 - 44 . 


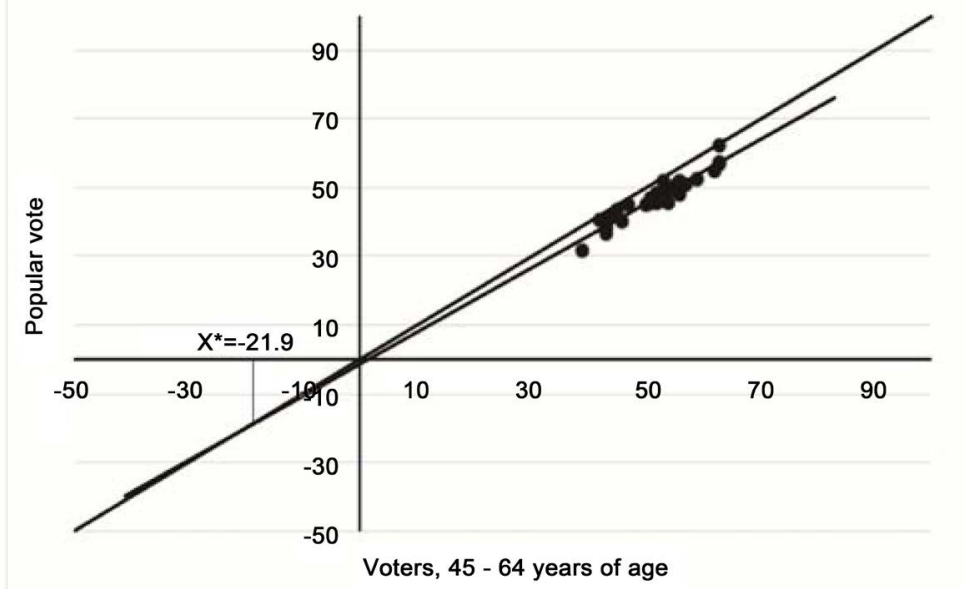

Figure 10. Exit poll results 2016, Trump voters ages 45 - 64 .

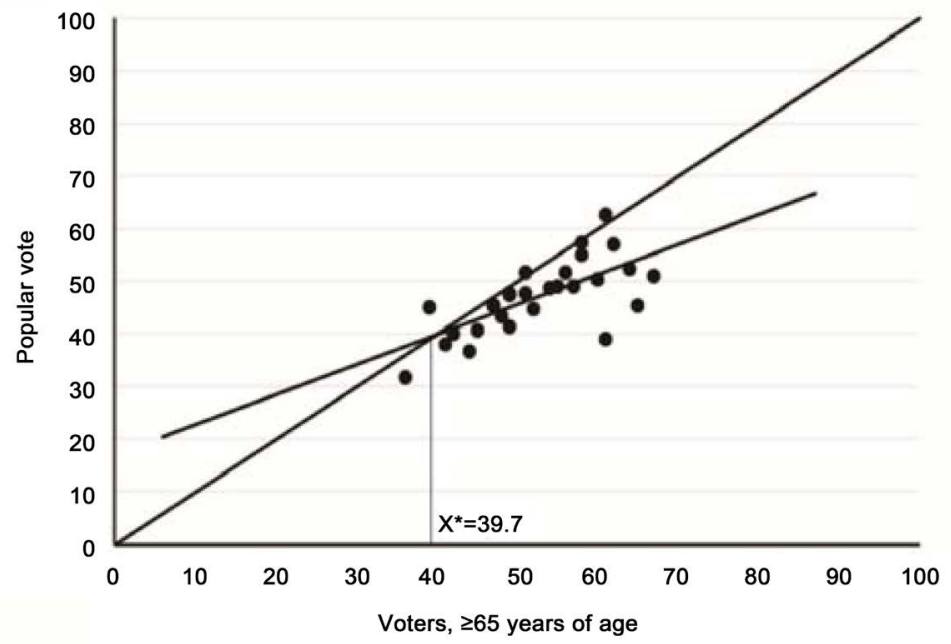

Figure 11. Exit poll results 2016, Trump voters ages $65+$.

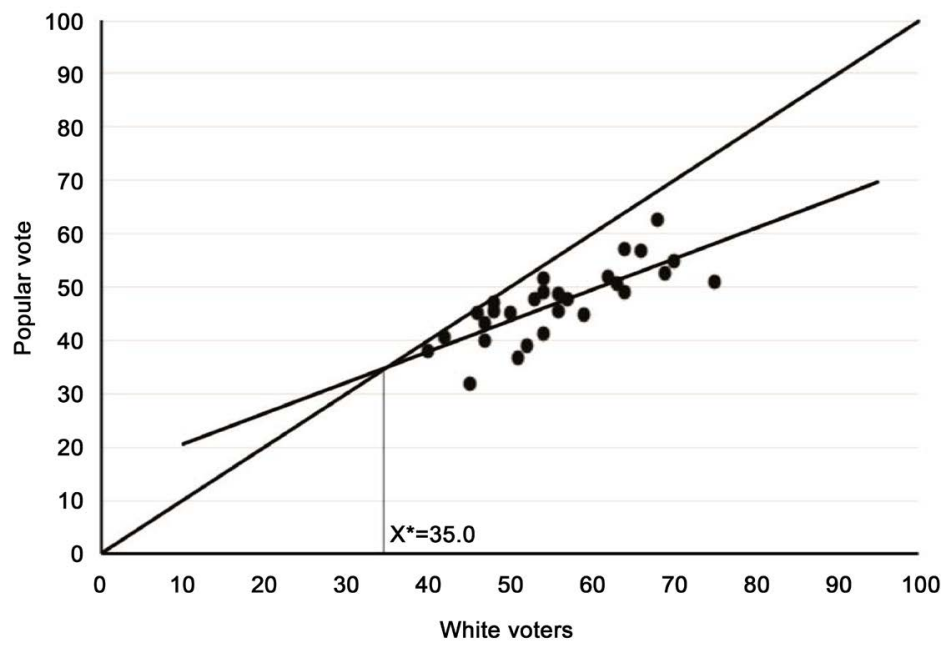

Figure 12. Exit poll results 2016, Trump voters who identify as white. 


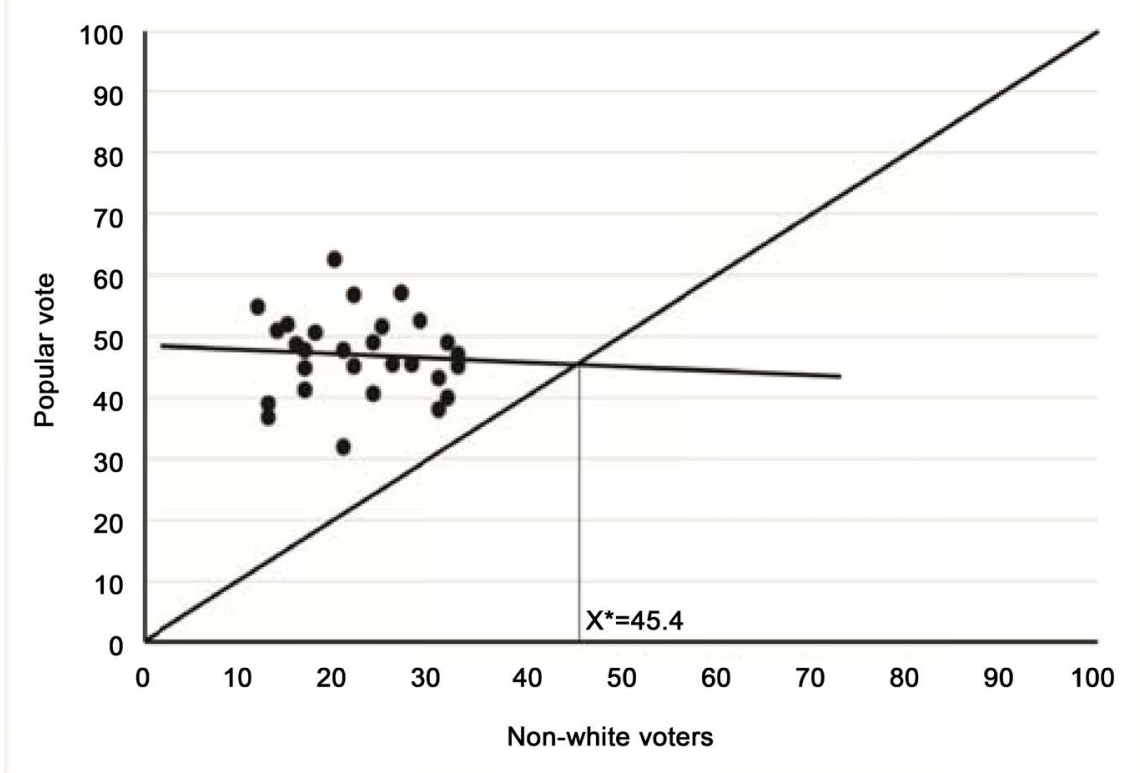

Figure 13. Exit poll results 2016, Trump voters who identify as non-white.

Table 2. Summary of Regression Results, 2016.

\begin{tabular}{|c|c|c|c|c|}
\hline Variable & Constant $\left(b_{o}\right)$ & Slope $\left(b_{1}\right)$ & $\mathbf{R}^{2}$ & Critical Point, $\mathrm{x}^{*}$ \\
\hline \multicolumn{5}{|l|}{ Education } \\
\hline High school & $17.2210(3.20)^{1 \star}$ & $0.5777(5.61)^{\star *}$ & 0.548 & 40.8 \\
\hline Some college & $-7.6340(-1.43)$ & $1.0700(10.28)^{\star *}$ & 0.803 & 109.1 \\
\hline College & $9.9997(3.90)^{* *}$ & $0.7946(14.64)^{\star *}$ & 0.892 & 48.7 \\
\hline Postgraduate & $27.4351(6.94)^{\star \star}$ & $0.5401(5.09)^{\star *}$ & 0.499 & 59.7 \\
\hline \multicolumn{5}{|c|}{$\begin{array}{c}\text { Income } \\
\text { (thousands of dollars) }\end{array}$} \\
\hline$<50$ & $14.4223(3.29)^{\star}$ & $0.7960(7.55)^{\star \star}$ & 0.695 & 70.7 \\
\hline $50-100$ & $9.5064(2.94)^{\star}$ & $0.7752(11.77)^{\star \star}$ & 0.847 & 42.3 \\
\hline$>100$ & $15.1985(4.23)^{\star \star}$ & $0.6357(9.02)^{\star *}$ & 0.765 & 41.7 \\
\hline \multicolumn{5}{|l|}{ Age } \\
\hline $18-29$ & $21.6678(6.42)^{\star \star}$ & $0.6835(7.85)^{\star *}$ & 0.720 & 68.5 \\
\hline $30-44$ & $14.9822(4.17)^{\star \star}$ & $0.7391(9.05)^{\star *}$ & 0.759 & 57.4 \\
\hline $45-64$ & $-1.4414(-0.46)$ & $0.9343(15.75)^{\star \star}$ & 0.905 & -21.9 \\
\hline 65 and older & $17.0778(2.76)^{\star}$ & $0.5702(4.89)^{\star \star}$ & 0.479 & 39.7 \\
\hline \multicolumn{5}{|l|}{ Race } \\
\hline White & $14.7694(2.84)^{*}$ & $0.5780(6.28)^{\star *}$ & 0.603 & 35.0 \\
\hline Non-white & $48.5584(10.52)^{\star \star}$ & $-0.0700(-0.36)$ & 0.005 & 45.4 \\
\hline
\end{tabular}

${ }^{1}$ Numbers in parentheses are $\mathrm{t}$-values; ${ }^{*}$ Denotes significance at better than the 0.01 level; ${ }^{*}$ Denotes significance at better than the 0.001 level. 
the most support from voters with a high school education, voters with annual incomes greater than $\$ 100,000$, voters 65 years of age or older, and white voters. One might predict that Trump's policies will reward these particular voter groups for their support. Trump was least popular among voters with a postgraduate degree, voters with annual incomes less than $\$ 50,000$, voters under 30 years of age, and non-white voters. Among voters with a postgraduate degree, Trump was only more popular than the general electorate (meaning his popular vote percentage exceeded the critical point of 59.7) in the state of Kentucky. Among voters with annual incomes less than $\$ 50,000$, Trump was not more popular than the general electorate, meaning Trump's popular vote percentage did not exceed the critical point of 70.7 in any state. Also, Trump was not more popular than the general electorate among voters under 30 years of age, meaning Trump's popular vote percentage did not exceed the critical point of 68.5 in any state. The coefficient of determination $\left(R^{2}=0.005\right)$ for the regression involving non-white voters (Figure 13) suggests that variation in Trump's support among non-white voters does not explain the variation in his support among all voters.

Two critical points are anomalies because the regression line through the scatter of points so closely follows a 45 -degree line. ${ }^{3}$ The critical point of -21.9 for voters 45 to 64 years of age suggests that Trump received more support from this group than the general electorate in all 28 states. That is, Trump's actual vote percentage exceeded " -21.9 " (that is, it was positive) among voters 45 to 64 years of age in all states. Figure 10 shows that the scatter plot closely follows a 45-degree line. The slope coefficient $(0.9343)$ is not discernably different from $1.0(p=0.278)$ and the constant term $(-1.4414)$ is not discernably different from zero $(p=0.646)$. In reality, Trump received the most support from voters aged 65 and older. ${ }^{4}$ The same type of problem occurred for the regression involving voters with "some college" education and a critical point that exceeded 100. Here again, the slope coefficient (1.070) is not discernably different from 1.0 ( $p=$ $0.507)$ and the constant term $(-7.6340)$ is not discernably different from zero ( $p$ $=0.165)$. For both groups, voters 45 to 64 years of age and voters with some college education, the percentage of voters who supported Trump was about equal to the percentage of Trump voters in the general electorate.

\section{Interpretation}

Throughout the campaign, Trump's voter base appeared to be uneducated, poor, non-millennial, and white. Our regression results affirm most of these characterizations, with one exception: Trump voters, despite their portrayal in the media, were not poor.

${ }^{3}$ For all other independent variables tested, either the slope coefficient was discernably different from 1 or the constant was discernably different from zero. The slope coefficients were all discernably different from 1 at better than the 0.01 significance level besides the slope for "under $\$ 50,000$ ", which was different from 1 at the 0.1 significance level. All constants were also discernable from zero at better than the 0.05 level.

${ }^{4} \mathrm{~A}$ paired $t$-test on the difference between Trump's average support among voters 65 years of age and older (52.4 percent) and his average support among voters 45 to 64 years of age (51.8 percent) was not discernably higher for the former group $(p=0.300)$. 
Our results show that the least educated voters (high school and some college) preferred Trump in the majority of states in our sample. In Figures 1-4, as educational attainment levels increase, the scatter of points shifts from below to above the 45-degree reference line, meaning that Trump was not as popular among people with higher levels of educational attainment. Trump appealed to uneducated voters throughout his campaign with his simple language and promise to bring change to the White House. Not surprisingly, a research analysis of the grammar and vocabulary used in Trump's campaign speeches found the reading level to average that of a $6^{\text {th }}$ grader (Moyer [3]).

The regression results are supported by a series of one-tailed paired $t$-tests performed on the four educational attainment levels. When "high school" is paired with "some college", there is no discernable difference between the two groups $(p=0.338)$. Thus, voters with some college education did not support Trump any less than voters with only a high school education. Support for Trump, however, is significantly lower among voters with either a college degree $(p=0.001)$ or postgraduate degree $(p<0.001)$ compared to voters with only a high school education. Similarly, support decreased from "some college" to "college" ( $p<0.001)$, from "some college" to "postgraduate" $(p<0.001)$, and even "college" to "postgraduate" $(p<0.001)$. As these critical points rise (from "high school" to "college" and "college" to "postgraduate"), Trump's popularity decreases.

We found that Trump was most popular among voters with annual incomes greater than $\$ 100,000$, thus, contradicting the stereotype of the poor Trump voter. McGill [4] examined exit poll results and similarly found that "only 23 percent of Trump's white, non-college-educated voters make less than $\$ 50,000$ a year." Trump's popularity was most likely due to his promises to enact enormous tax cuts, similar to those of the Reagan era. These tax cuts would cause "the top $1 \%$ of earners to see their [annual] income increase by double-digits" (BBC News [5]).

Younger voters tend to support more liberal, progressive candidates. A study by Harvard University (Ball [6]) showed that millennials, the cohort of 18- to 29-year-olds, overwhelmingly supported candidate Bernie Sanders. That is, millennials would support Clinton if they had no other choice. Figures 8-11 show that the scatter of points moves from above to below the 45-degree reference line, indicating that Trump received increasingly more support from older cohorts.

Finally, Trump strongly appealed to white voters due to his platform on immigrants and refugees, claiming that these groups were taking away opportunities from white Americans. His promises to "build a wall" to keep out illegal immigrants from Mexico and to persecute Muslims for their alleged role in terrorism appealed to white voters who felt powerless in the current political system. These same promises alienated non-white voters and turned them away from Trump's campaign (Thompson [7]).

A number of shortcomings of this study should be kept in mind. First, the 
network conducting the exit poll may not, as in our case, have data for all 50 states. Edison Research, the exclusive provider of the national election exit polls to major U.S. television news networks, including $\mathrm{CNN}$, conducted a detailed statewide exit poll (by age and income group) in 31 of the states in 2012 and 28 states in 2016. Events that occur just days before an election (like the FBI's investigation into Hillary Clinton's emails) may influence voters (included in election-day exit polls) differently from early and absentee voters. And, finally, some people have questioned the randomness of the samples of the state in which exit polls take place, selecting precincts where the poor and minorities are allegedly underrepresented.

\section{Concluding Remarks}

One can gauge the popularity of a candidate across different demographic and socioeconomic groups of voters. This can be done by means of regressions between a candidate's actual percentage of the total vote and his (or her) support among voters in a particular group (defined by age, income, or race) fitted to the cross-section of states with election exit poll data.

In 2016, Trump's strongest supporters had no more than a high school diploma. They were also largely non-millennial and white. Among income groups, however, Trump was surprisingly most popular with voters earning more than $\$ 100,000$ per year. This comprehensive analysis of Donald Trump's main voter base helps us understand the current political landscape and the values that may shape his new policies.

\section{References}

[1] Silver, N. (2016) "Who Will Win the Presidency?" N.p. https://projects.fivethirtyeight.com/2016-election-forecast/

[2] CNN Politics (2016) "Exit Polls." N.p. http://edition.cnn.com/election/results/exit-polls/national/president

[3] Moyer, J.M. (2016) “Trump's Grammar in Speeches 'Just below $6^{\text {th }}$ Grade Level' Study Finds." N.p.

https://www.washingtonpost.com/news/morning-mix/wp/2016/03/18/trumps-gram mar-in-speeches-just-below-6th-grade-level-study-finds/?utm_term=.08f14770ale8

[4] McGill, A. (2016) "Trump Bloc." N.p. http://www.theatlantic.com/politics/archive/2016/09/dissecting-donald-trumps-sup port/499739/

[5] BBC (2016) "First 100 Days: Where President Trump Stands on Key Issues." N.p. http://www.bbc.com/news/election-us-2016-37468751

[6] Ball, M. (2016) “Trump’s Graying Army.” N.p. https://www.theatlantic.com/politics/archive/2016/10/trumps-graying-army/505274/

[7] Thompson, D. (2016) “Who Are Donald Trump's Supporters, Really?” N.p. http://www.theatlantic.com/politics/archive/2016/03/who-are-donald-trumps-supp orters-really/471714/ 
Submit or recommend next manuscript to SCIRP and we will provide best service for you:

Accepting pre-submission inquiries through Email, Facebook, LinkedIn, Twitter, etc. A wide selection of journals (inclusive of 9 subjects, more than 200 journals)

Providing 24-hour high-quality service

User-friendly online submission system

Fair and swift peer-review system

Efficient typesetting and proofreading procedure

Display of the result of downloads and visits, as well as the number of cited articles Maximum dissemination of your research work

Submit your manuscript at: http://papersubmission.scirp.org/

Or contact jss@scirp.org 